\title{
Study of impulse buying on Instagram users in Indonesia
}

\author{
Sri Rahayu Tri Astuti¹, Imroatul Khasanah¹, and Yoestini \\ ${ }^{1}$ Department of Management, Faculty of Economics and Business, Universitas Diponegoro, Indonesia
}

\begin{abstract}
Our paper is aimed to find out the effect of online advertisement content, electronic word of mouth (e-WOM) and hedonic shopping motives on impulse buying of Indonesian users in Indonesia. Multiple linier regression analysis is used to examine the magnitude of independent variables effect which are online advertisement content, e-WOM and hedonic shopping motives on impulse buying on instagram user in Indonesia. The analysis on 75 respondents showed that all independent variables have positive and significant effect on dependent variable. The independent variabel which has the biggest effect on impulse buying in order are online advertisement content, e-WOM and hedonic shopping motives. The main reason affecting the decision from impulse buying is good online advertisement content which is marked by informative, easily understood, easily accessed contents and its attractive visualisation. The practical implications of this study are of most interest for advertisers, marketers, online retailer and designers of shopping website.
\end{abstract}

Keywords online advertisement content; electronic word of mouth (e-WOM); hedonic shopping motives; impulse buying; Indonesia

\section{INTRODUCTION}

The shift in business transactions from conventional media to online media has continued in recent years, one of which is through social media. This is inseparable from the increasing number of social media users. This phenomenon also occurs in Indonesia. As reported by wearesocial.net and Hootsuite (2018), some of the leading social media in Indonesia are Youtube, Facebook, Whatsapp, and Instagram.

Apart from the large number of users, another reason that business owners market their products through social media is because they are considered to significantly increase sales. They argue that marketing through social media can make people do impulse buying. This argument supported by Chan, Cheung \& Lee (2017) who argued that the advancement of information technology and the extraordinary growth of e-commerce have made all online consumer spending due to impulsive online purchases. Researchers believe that the online shopping environment is now more conducive to impulse buying behavior than offline stores.

Several studies have been conducted to explore the antecedents of impulse buying. Some of the variables that emerge include online advertisement content (Seng and
Khalifa, 2012; Dawson and Kim, 2009; and Chen, Bo-Su and Widjaja, 2016); electronic word of mouth (e-WOM) (Zhang et al, 2018; Husnain, et al., 2016); hedonic shopping motives (Zhenga et al, 2019; Park et al, 2012).

However, the empirical evidence related the relationship between those variables in the Indonesian context is still very limited. For Indonesia, which is one of the largest social media users in the world, this information is certainly very valuable for the business community as a base for formulating business decision. In addition, the objects of previous studies are still very common, while the majority of social media users are in the age range of 18-24 years (wearesocial.net and Hootsuite, 2018). Therefore, this study attempts to examine the effect of online advertisement content, electronic word of mouth., and hedonic shopping motives on impulse buying with the object of Instagram users aged 18-24 years in Indonesia.

\section{LITERATURE REVIEW AND HYPOTHESES DEVELOPMENT}

\section{Impluse buying}

Impulse buying (unplanned buying) is the buying decision examined by the customer 
of a place after looking at the stuff or product. (Utami, 2010). Silvera, Lavack and Kropp (2008) said impulsive buying behavior consists of unplanned and sudden purchases, the cognitive and affective forces that drive purchases usually begin at the time and place of purchase.

Impulsive buying is often accompanied by strong affective reactions such as a strong urge to buy or a feeling of excitement. Impulsive buying, described as unplanned, attractive, and hedonic buying behavior, has been widely studied in academia and business for decades. Kharis (2011) quoting from Loudon, Della Bitta and Stren, there are several types of impulse buying: (1) pure Impulse (purchase of pure impulse); (2) suggestion Impulse (purchase of impulses arising from suggestions); (3) impulse reminder (impulse purchase due to past experience); and (4) planned Impulse (impulse purchases that occur when certain sales conditions are given).

\section{Online advertisement content and impulse buying}

Online advertisement content is all aspects and elements becoming the part of that advertisement including color, lighting, model, text and all elements supporting the ad. (Chen, Su and Widjaja, 2016). Theoretically, online advertising can create the right advertising message according to the needs, desires, and values of each consumer. Online advertising also provides opportunities for interactive 2-way communication between advertisers and potential consumers (Laudon and Traver, 2012). One type of online advertising is through social networking. Social networking advertising (or social media) is part of social advertising, which is another aspect of social commerce, that is, using social graphics to communicate brand image and to promote sales of goods and services directly (Laudon and Traver, 2012). Ads on social media must also provide information that is easily understood by consumers. Logan, Bright and Gangadharbatla (2012) suggested that social media users more quickly understand advertising information on social media, more information that advertisements provide to consumers about new products, specific advantages of products, and product comparison information, this adds more value effective (Saxena \& Khanna, 2013).
Instagram is a social media that emphasizes the visualization in its appearance, which prioritizes interesting photos and videos compared to text. Items that stand out more visually because of the brightness, color, size, number of filters used, cause the item to stand out from the screen, direct automatic attention directly to the item, which increases the duration of fixation and can influence subsequent preferences and can be an important factor that can attract attention consumers and cause impulse buying. (Kahn, 2017). One source of information for consumers to see original product reviews from other consumers who have already bought and used it, both in terms of the quality of the goods or the credibility of the seller is through the comments column available on Instagram.

The research of Seng and Khalifa (2012) showed that there is positive effect between advertisement content on impulse buying. Study conducted by Dawson and Kim (2009) also found that there is positive effect between advertisement appearance in website and impulse buying. Chen, Bo- Su and Widjaja (2016) finding also revealed that there is positive effect between advertisement content on impulse buying. Furhermore, research of Akram et al (2017) showed that there was a positive effect between advertisement content on impulse buying.

H1: Online advertisement content affects positively on impulse buying.

\section{Electronic word of mouth (e-WOM) and impulse buying}

Electronic word of mouth (E-WOM) defined as the positive or negative statements made by the potential customer, subscribing customer or ex customer about the product or company made for many people or institution through internet ( Alhidari and uta, 2015). Sumardy, Silviana and Melone (2011) define WOM is the act of consumers providing information to other consumers or C-2-C (consumer to consumer).

WOM consists of 2 types: (1) organic WOM is WOM that occurs naturally. People are happy and satisfied with a product, have a natural desire to share their support and enthusiasm; and (2) amplified WOM is WOM that occurs by design by the company. This type of WOM occurs when 
marketers/companies carry out campaigns designed to encourage or speed up WOM to consumers.

Pai et al (2013) say e-WOM is a way of expressing opinions about a product or service, and opinions are very important for consumer knowledge. Hennig-Thurau et al (2004) explain e-WOM as a positive or negative expression that comes from actual, potential or previous consumers about a product or company in which the information can be accessed or seen by many people or institutions through the internet media. Chu and Kim (2011) stated that consumers who tend to search for opinions are more likely to seek advice and information from other consumers when making a purchase. Whereas consumers who tend to give opinions will have a significant impact on the behavior and habits of other consumers.

The research from Zhang et al. (2018) showed that there is a positive effect between e-WOM in this term online rewiews on impulse buying. The research from Husnain et al. (2016) also confirmed a positive effect of e-WOM on impulse buying. Furthermore, study by Zafar et al. (2019) showed that there is a positive and significant effect between e-wom on impulse buying.

H2: e-WOM has positive effect on impulse buying.

\section{Hedonic shopping motives and impulse buying}

Hedonic shopping motives is consumer hedonic motivation to shop because shopping is certain pleasure therefore the advantage of the purchased product is not really cared for (Utami 2010). Hedonic shopping is a value of one's shopping experience that includes fantasy, censorship, stimulation, excitement, pleasure, curiosity and delusion (Scarpi, 2006). Hedonic shopping motivation according to Utami (2010) is the motivation of consumers to shop because shopping is a pleasure in itself so that it does not pay attention to the benefits of the product purchased.

There are six motivational factors for hedonic shopping according to Arnold and Reynolds (2003), namely: (1) adventure shopping, which based on the desire to shop from the individual himself because he feels happy when shopping. They assume that shopping as a means to find experiences about new things; (2) social shopping, which based on the pleasure of individuals socializing with others. Individuals assume that by interacting with other people will get more information about the product to be purchased; (3) gratification shopping, which based on the assumption of individuals that shopping can reduce feelings of stress, improve their bad moods and as an escape to forget the problem at hand; (4) shopping idea, which based on individual curiosity about the development of a new product or innovation. They assume that shopping as a means to follow new trends or fashions. Usually consumers shop after seeing the promotions carried out by the company; (5) role shopping, this factor is based on the pleasure of individuals shopping for other people. They feel happy if they find something for others, so they think that shopping for other people is a fun activity; and (6) value shopping, which based on consumers' pleasure to seek benefits in shopping. They feel happy to look for discounts or low prices. They assume that looking for discounts or low prices as a race that must be "won".

Research from Zhenga et al (2019) viewed hedonic browsing and utilitarian browsing as two key drivers on impulse buying in mobile commerce. Hedonic browsing directly and positively influences consumers' urge to buy impulsively. Zhenga et al (2019) stated that the study confirms that two types of web browsing occur: utilitarian and hedonic. In an estimated structural the model, the variety of selection has a positive effect on utilitarian web browsing, whereas the price has a positive effect on hedonic web browsing. Additionally, utilitarian web browsing has a negative effect on impulse buying whereas hedonic web browsing has a positive effect on impulse buying for apparel on shopping websites

Lutfiana (2014) showed that there is positive effect between hedonic shopping motives and impulse buying. This research is also supported by the research from Park et al (2012) showing that there is positive effect of hedonic web browsing variable on impulse buying.

H3: Hedonic shopping motives has positive effect on impulse buying. 
Table 1.

Respondents profile

\begin{tabular}{ccccccc}
\hline Gender & Amount & $\begin{array}{c}\text { Age } \\
\text { (Year Old) }\end{array}$ & Amount & University & Amount & $\begin{array}{c}\text { Online shopping } \\
\text { frequency } \\
\text { (Last 2 month) }\end{array}$ \\
\hline Male & 30 & $19-22$ & 65 & State Univ. & 54 & $1-3$ times \\
Female & 45 & $22-26$ & 10 & Private Univ. & 21 & $>3$ times \\
\hline Total & $\mathbf{7 5}$ & & $\mathbf{7 5}$ & & $\mathbf{7 5}$ & 20 \\
\hline
\end{tabular}

\section{METHODS}

Research population reffered to the number of instagram user. Since the population in this study is spread and hard to know the exact number thus sampling is done for this study so we need samples. Sampling technique is non probability sampling technique using purposive sampling approach subjectively (Ferdinand, 2013). Purposive sampling is done because probably the researcher has comprehended that information needed could be obtained from one certain aimed group who were able to give information desired because they did have that certain information and they fulfilled the criteria set by the researcher. In multivariate research (including one using multivariate regression analysis) the sample minimum number setting is based on the formulation as follow (Ferdinand, 2013) $\mathrm{N}=$ $25 \times 3$ independent variable $=75$ samples. In this research, the answer given is scored with certain scale. As presented in Table 1, majority respondents are female, 19-22 years old, students in state university, and have 1-3 times experiences to make shopping online in the last 2 months.

Primary data in this research is the questionnaire data from instagram user selected as respondents. Data collection was conducted on November 15-22 November 2019, data was collected through an online questionnaire on the link: bit.ly/lmpulseBuying2. Selected 75 of 122 respondents according to the number of samples requested.

\section{Measurements}

Impulse buying was measured using three indicators developed by Kharis (2011) \& Utami (2010) and scored using Likert scale ranging from strongly agree to strongly disagree. Those items are: (1) buying spontaniety; (2) not considering product value; (3) unplanned buying. Online advertisement content was measured using four indicators and scored using Likert scale ranging from strongly agree to strongly disagree. Those items are: (1) informative; (2) easily understood; (3) easily accessed; and (4) attractive visualization.

E-wom was measured using four indicators developed by Alhidari and lyer (2015) and scored using Likert scale ranging from strongly agree to strongly disagree. Those items are: (1) sharing experience to others through internet; (2) giving opinion to others through internet; (3) sharing related link/video/photo through internet; and (4) internet becomes important and main thing to find information. Hedonic shopping moitives was measured using three indicatorsand scored using Likert scale ranging from strongly agree to strongly disagree. Those items are: (1) choosing selected product as desired/ to taste; (2) getting sensation/ satisfaction; and (3) forgetting time when shopping because of being busy choosing the product.

\section{Data analysis}

Our study used quantitative analysis which could be defined as an analysis method with numbers which could be counted or measured. This quantitative analysis is meant for predicting the magnitude of effect quantitatively from one change or other several events by using statistic analysis tools. Spss (statistical package for social science) for windows 23 is used to examine the proposed hypothesis.

Table 2.

The result of multiple linear regression analysis

\begin{tabular}{|c|c|c|c|c|c|}
\hline \multirow{2}{*}{ Variable } & \multicolumn{2}{|c|}{$\begin{array}{l}\text { Unstandardized } \\
\text { Coefficients }\end{array}$} & \multirow{2}{*}{$\begin{array}{c}\text { Standar } \\
\text { dized } \\
\text { Coeffici } \\
\text { ents }\end{array}$} & \multirow{2}{*}{$t$} & \multirow{2}{*}{ Sig. } \\
\hline & B & $\begin{array}{l}\text { Std. } \\
\text { Error }\end{array}$ & & & \\
\hline $\begin{array}{l}\text { Online } \\
\text { Adv. } \\
\text { Content }\end{array}$ & 0.243 & 0.122 & 0.230 & 1.985 & 0.051 \\
\hline e-WOM & 0.194 & 0.104 & 0.228 & 1.864 & 0.066 \\
\hline $\begin{array}{l}\text { Hedonic } \\
\text { shopping }\end{array}$ & 0.224 & 0.144 & 0.183 & 1.554 & 0.125 \\
\hline
\end{tabular}


In order to examine the hypotheses, our study employed multiple regression analysis which usually used to know the magnitude of independent variables effect which are online advertisement content $\left(X_{1}\right)$, E-WOM $\left(\mathrm{X}_{2}\right)$ and hedonic shopping motives $\left(\mathrm{X}_{3}\right)$ on impulse buying $(Y)$ on instagram user.

\section{RESULTS AND DISCUSSION}

\section{Multiple linear regression analysis}

Multiple linear regression analysis was used to predict the state of dependent variable, if two or more independent variables as predictor factor are manipulated (the value is fluctuated) Multiple linear regression analysis will be applied if there are at least two independent variables (Sugiyono, 2014). In this research, multiple linear regression analysis is used to analyze the effect of independent variable which are online advertisement content (X1), e-wom (X2) and hedonic shopping motives (X3) on the dependent variable of impulse buying $(Y)$. The result of the multiple linear regression analysis could be seen on the Table 2 .

From the table, it could be explained that regression coefficient of online advertisement content is 0,230 in positive direction. This means that there is positive effect from online advertisment content on impulse buying. Therefore if online advertisement content is more positive, thus impulse buying could also increase, with the assumption if e-WOM and hedonic shopping variable is static or zero. From the above equation it could be concluded that online advertisement content variable could be the most influencing variable on impulse buying. The result from Table 2 also suggested that regression coefficient of e-WOM is 0,228 in positive direction. This means that there is a positive effect from e-WOM on impulse buying. If e-WOM is more positive, thus impulse buying will also increase more, with the assumption that if online advertisment

Table 3.

Determination coefficient test result $\left(\mathbf{R}^{2}\right)$

\begin{tabular}{ccccc}
\hline Model & $\mathbf{R}$ & $\begin{array}{c}\mathbf{R} \\
\text { Square }\end{array}$ & $\begin{array}{c}\text { Adjusted } \\
\mathbf{R} \\
\text { Square }\end{array}$ & $\begin{array}{c}\text { Std. } \\
\text { Error of } \\
\text { the } \\
\text { Estimate }\end{array}$ \\
\hline 1 & 0,503 & 0,253 & 0,222 & 2,409 \\
\hline
\end{tabular}

content and hedonic shopping motives variables' value is static or null.

From Table 2, it can be seen that regression coefficient of hedonic shopping motives is 0,183 in positive direction. This means that there is positive effect of hedonic shopping motives on impulse buying. If hedonic shopping motives is positive, so impulse buying will also increase with the assumption that the variables of online advertisement content and e-WOM are static or null.

\section{Determination coefficient test $\left(\boldsymbol{R}^{2}\right)$}

The determination coefficient tested variation of dependent variables. The value of determination coefficient is between null or zero to one. The capability of independent variables to explain the limited dependent variables is marked with small $R^{2}$ score. While the independent variables which give almost all information needed in predicting dependent variables are marked with the value approaching one (Ghozali, 2017).

From Table 3, it could be seen that adjusted $R$ square score is 0,222 . The value in that adjusted $R$ square shows the capability of the independent variables which are online advertisement content, eWOM, and hedonic shopping motives in explaining impulse buying as dependent variable in this research which is $22 \%$ and the rest $88 \%$ is explaind by other independent variables outside this research.

\section{Model fit test (f statistic test)}

F statistic test as presented in Table 4 showed the model feasibility/goodness of fit (fit model). The model proposed is considered fit if $F$ calculate $>F$ Table with significance probability number $<0,05$ (Ghozali, 2017).

The statistics test result shows that $F$ calculate is 8,036 with significance 0,000 . While the value of $F$ table for sample of 75 and 4 variables is 2,734 and the significance

Table 4.

F Statistics test result

\begin{tabular}{|c|c|c|c|c|c|}
\hline Model & $\begin{array}{l}\text { Sum of } \\
\text { Squares }\end{array}$ & df & $\begin{array}{c}\text { Mean } \\
\text { Square }\end{array}$ & $\mathbf{F}$ & Sig. \\
\hline 1 Regression & 139.871 & 3 & 46.624 & 8.036 & $.000^{\mathrm{b}}$ \\
\hline Residual & 411.915 & 71 & 5.802 & & \\
\hline Total & 551.787 & 74 & & & \\
\hline
\end{tabular}

a. Dependent Variable: total Impulse

b. Predictors: (Constant), total Hedonic, total Content, Total EWOM 
Table 5.

Hypothesis test result (t Test)

\begin{tabular}{lccc}
\hline \multicolumn{1}{c}{ Variable } & T Calculate & T Table & Sig. \\
\hline $\begin{array}{l}\text { Online } \\
\text { Advertisment } \\
\text { Content }\end{array}$ & 1,985 & 1,99 & 0,051 \\
\hline E-WOM & & & \\
\hline $\begin{array}{l}\text { Hedonic } \\
\text { Shopping }\end{array}$ & 1,864 & 1,99 & 0,066 \\
Motives & 1,554 & 1,99 & 0,125 \\
\hline
\end{tabular}

should be below 0,05 . The result is $F 8,036$ $>2,734$ and the significance $0,000<0,05$. Therefore, it could be stated that the model proposed in this research appropriate or fit.

\section{Hypothesis test}

In this research, the hypothesis testing was conducted by t statistics test. The decision making basic is by using critical ratio If $t$ calculate $>\mathrm{t} \mathrm{Table,} \mathrm{thus} \mathrm{Ha}$ is accepted and $\mathrm{HO}$ is rejected. If $\mathrm{t}$ calculate $<\mathrm{t}$ Table, thus $\mathrm{Ha}$ is rejected and $\mathrm{HO}$ is failed to be rejected.

As showed in Table 5, several conclusions could be drawn as follow. Based on the result, it is shown that $t$ calculate value of online asvertisement content variable is $1,985<\mathrm{t}$ Table value which is 1,99 with significance above 0,05 which is 0,051 . Therefore $\mathrm{Ha}$ is rejected and $\mathrm{Ho}$ is failed to be rejected. The coefficient direction is positive, meaning that the online advertisement content affects impulse buying positively. This finding suggested that the phenomenon of impulse buying in Indonesia is also predicted by online advertisement content. It supports the results from studies which were conducted in another setting, such as Seng and Khalifa (2012), Dawson and Kim (2009), Chen, BoSu and Widjaja (2016), and Akram et al (2017).

Based on the results from Table 5, it could be seen that the $t$ calculate value of $e$ WOM is $1,865<\mathrm{t}$ Table value of 1,99 with significance level above 0,05 which is 0,066 .
Therefore $\mathrm{Ha}$ is rejected and $\mathrm{Ho}$ is failed to be accepted. The direction of the coefficient is positive meaning that e-WOM has positive effect on impulse buying. This result support our hypothesis which predict that in Indonesian context, e-WOM also has positive effect on impulse buying. It supports the results from studies which were conducted in another setting, such as Zhang et al. (2018), Husnain et al. (2016), Zafar et al. (2019).

Table 5 also shows that $t$ calculate value of hedonic shopping motives is 1,554 < t Table value of 1,99 with significance level above 0,05 which is 0,125 . Therefore $\mathrm{Ha}$ is rejected and $\mathrm{Ho}$ is failed to be rejected. The direction of the coefficient is positive, meaning that hedonic shopping motives has positive effect on impulse buying. This finding suggested that the activities od impulse buying of Indonesian Instagram users in Indonesia is also predicted by hedonic shopping motives. It supports the results from studies which were conducted in another setting, such as Park et al (2012). Table 6 shows the summary of hypotheses testing results.

\section{CONCLUSIONS}

In this research it could be concluded that the main reason affecting the decision from impulse buying is good online advertisement content which is marked by informative, easily understood, easily accessed contents and its attractive visualisation. In this research it could also be concluded that there are other reasons affecting impulse buying which are e-wom and hedonic shopping motives. The results of this study support from previous research from Akram, et al (2017), Husnain, et al (2016) and Zhenga et al (2019). E - wom itself is marked by the existing activities of sharing experiences with others through internet, giving opinion to others through internet, sharing related link/video/photo through internet and making internet as an important

Table 6.

Summary of hypotheses testing result

\begin{tabular}{cll}
\hline No & \multicolumn{1}{c}{ Hypothesis } & Findings \\
\hline $\mathbf{1}$ & $\begin{array}{l}\text { Online advertisment content affects impulse buying } \\
\text { positively. }\end{array}$ & Supported \\
$\mathbf{2}$ & E-WOM affects impulse buying positively & Supported \\
$\mathbf{3}$ & Hedonic shopping motives affects impulse buying positively. & Supported \\
\hline
\end{tabular}


and main source in finding information. While hedonic shopping motives is marked by the ability of customers in selecting products to their taste, sensation gaining or inner satisfaction, and the customers who forget time when they do shopping because they are really carried away when selecting products.

From the findings of our study, it could be known that the online advertisement content has big effect on impulse buying, compared to e-wom and hedonic shopping motives. Therefore, to increase customers' impulse buying, it is suggested that the online shops could increase the quality of their online advertisement contents. The infomation on the advertisement should be complete, such as the availability of information about the function of the sold product, price, size, types of product and the variants, material used, review or judgment from the previous buyer, photos from various angles and how to order. Beside the completeness of information, the advertisement should also be easily understood with the short, simple and clear presentation. Customers also like easily accessed advertisements, which are the advertisements which have already been connected directly to the account of the online shop.

This could be done with the available website, catalogue, instagram account or contact person who could be contacted if the customer wants to order for the product. The last indicator from the advertisement content which could affect impulse buying is the attractive advertisement visualization. Some customers consider the advertisement visualization is interesting if it is packed in simple way but it has aesthetic or beauty values. While others consider attractive advertisement visualization is eye catching and creative advertisement.

The practical implications of this study are of most interest in advertisers, marketers, online retailer and designers of shopping website, specially to manager who have to take decision.

Above all of the contributions, our study as another research also have several limitations. One of the limitations is related to the number of samples, the number of independent variables and simple analysis tools. For future research, it should be able to add a number of samples, the number of independent variables, for example, can be added utilitarian browsing or the influence of celebrity endorsement. Analysis tools can use the Structural Equation Model. For research objects, it can examine young adult marketing targeting young professionals typically ages 25 to 34 .

\section{REFERENCES}

Akram, U., Hui, P., Khan, M. K., Tanveer, Y., Mehmood, K., \& Ahmad, W. (2018) How website quality affects online impulse buying: Moderating effects of sales promotion and credit card use. Asia Pacific Journal of Marketing and Logistics, 30(1).

Alhidari, Abdullah and lyer, Pramod A. P. (2015). Personal level antecedents of E-WOM and purchase intention, on social networking sites. Journal of Customer Behavior, 14(2), 107-125. https://doi.org/http://dx.doi.org/10.1362/ 147539215X14373846805707

Arnold, M. J., \& Reynolds, K. E. (2003). Hedonic shopping motivations. Journal of Retailing, 79(2), 77-95.

Chan, T. K. H. And Cheung, C. M. K. And Lee, Z. W. Y. (2017). The State of Online Impulse-buying Research: A Literature Analysis. Information management, 54 (2), 204-217.

Chen, J. V., Su, B. C., \& Widjaja, A. E. (2016). Facebook C2C Social Commerce: A study of online impulse buying. Decision Support Systems, 83, 57-69. Https://doi.org/10.1016/j.dss.2015.12.0 08

Chu, S., \& Kim, Y. 2011. Determinants of Consumer Engagement in Electronic Word-of Mouth (E-WOM) in Social Networking Sites. International Journal of Advertising, 30(1), pp. 47-75.

David H. Silvera, David H, Lavack, Anna M, Kropp, Fredric (2008). Impulse buying: the role of affect, social influence, and subjective wellbeing. Journal of Consumer Marketing, 25(1), 23-33.

Dawson, S., \& Kim, M. (2010). Cues on apparel web sites that trigger impulse purchases. Journal of Fashion Marketing and Management, 14(2), 230-246. https://doi.org/10.1108/1361202101104 6084

Ferdinand, Augusty. (2013). Metode Penelitian Manajemen Edisi 5. Semarang: Badan Penerbit Universitas Diponegoro.

Ghozali, Imam. (2017). Model Persamaan Struktural Konsep dan Aplikasi dngan Program AMOS 24 Udate Bayesian SEM Edisi 7. Semarang. Badan 
Penerbit Universitas Diponegoro. ISBN:979.704.233.2

Hennig- Thurau, T., Gwinner, K. V., Walsh, G., \& Gremler, D. D. (2004). Electronic Wordof-Mouth via Consumer-Opinion Platforms: What Motivates Consumers to Articulate Themselves on the Internet? Journal of Interactive Marketing, 18(1): 38-52.

Husnain, M., Qureshi, I., Fatima, T., \& Akhtar, W. (2016). The impact of electronic word-ofmouth on online impulse buying behavior: The moderating role of Big 5 personality traits. $J$ Account Mark, 5(190), 1-10.

Instagram Marketing. (2018).

Kahn, B. E. (2017). Using Visual Design to Improve Customer Perceptions of Online Assortments. Journal of Retailing, 93(1), 29-42. Https://doi.org/10.1016/j.jretai.2016.11. 004

Kathy Ning Shen, Mohamed Khalifa. (2012). System Design Effects on Online Impulse Buying. Internet Research, 22(4), 396425. https://doi.org/10.1108/106622412 11250962

Kem Z.K. Zhang, Haiqin Xu, Sesia Zhao, Yugang Yu. (2018). Online reviews and impulse buying behavior: the role of browsing and impulsiveness. Internet Research, 28(3),

$522-$ 543. https://doi.org/10.1108/intr-122016-0377

Kharis, I. F., \& Indriani, F. (2011). Studi Mengenai Impulse Buying dalam Penjualan Online (Studi Kasus di Lingkungan Universitas Diponegoro Semarang) [Doctoral dissertation, Universitas Diponegoro].

Laudon, Kenneth C., \& Traver C.G. (2012). Ecommerce 2012, Bussiness, Technology, Society (8th ed.). Pearson Education Limited.

Logan, K., Bright, L. F., \& Gangadharbatla, H. (2012). Article information: Facebook versus television: advertising value perceptions among females. Journal of Research in Interactive Marketing, 6(3), $164-179$.

Lutfiana, Revalia. (2014). Analisis Kualitas Layanan, Promosi dan Hedonic Shopping Motives yang Mempengaruhi Impulse Buying pada Belanja Online (Studi pada Mahasiswi FEB Undip Semarang) [Doctocal Dissertation, Universitas Diponegoro]. eprints. http://eprints.undip.ac.id/42873/
Pai, M.-Y., Chu, H.-C., Wang, S.-C., \& Chen, Y.M. (2013). Ontology-based SWOT analysis method for electronic word-ofmouth. Knowledge-Based Systems, 50,134-150.

Park, Eun Joo, Kim, Eun Young, Funchess, Venessa Martin, Foxx, William. (2012). Apparel Product Attributes, Web Browsing and E-impulse Buying on Shopping Website. Journal of Business Research, 65(2012), 1583-1589.

Saxena, A., \& Khanna, U. (2013). Advertising on Social Network Sites: A Structural Equation Modelling Approach. Vision: The Journal of Business Perspective, 17(1), 17-25. Https://doi.org/10.1177/0972262912469 560

Scarpi. D. (2006). Fashion Stores Between Fun and Usefulness. Journal of Fashion Marketing and Management, (10) 1 : 724.

Sugiyono. (2014). Metode Penelitian Bisnis. Alfabeta.

Sumardy, Silviana, Marlin \& Melone, Melina. (2011). The Power of Word of Mouth Marketing. PT Gramedia Pustaka Utama.

Utami, Christina Whidya. 2010. Manajemen Ritel (2nd ed.). Salemba Empat.

Wikipedia. (2017). Accessed 19 March 2019.

Zafar, A. U., Qiu, J., Li, Y., Wang, J., \& Shahzad, M. (2019). The impact of social media celebrities' posts and contextual interactions on impulse buying in social commerce. Computers in Human Behavior, 106178.

Zeng, F., Huang, L., \& Dou, W. (2009). Social Factors in User Perceptions and Responses to Advertising in Online Social Networking Communities. Journal of Interactive Advertising, 10(1), $1-13$. https://doi.org/10.1080/15252019.2009. 10722159

Zheng, X., Men, J., Yang, F., \& Gong, X. (2019). Understanding impulse buying in mobile commerce: An investigation into hedonic and utilitarian browsing. International Journal of Information Management, 48, 151-160. 